\title{
6.8 Критичне мислення та еко-творчий аудит як базис професійної інтерпретаційної діяльності у сфері дизайну
}

Художньо-естетична інтерпретація - процес, який не функціонує при обмеженій свідомості та умовності пізнання. Формування розуміння у майбутніх дизайнерів аналітико-чуттєвого естетичного аналізу явищ, об’єктів та процесів натурального оточення - $є$ неоціненним в умовах глобальної комерціоналізації інтерпретаційних художніх здобутків, задля впливу на свідомість потенційного користувача. Орієнтуючись на науковий доробок С. Чирчика [451], О. Шикирінської [452], стосовно інтерпретаційної компетенції особистості, ми поділяємо їхню думку стосовно організації інтерпретаційного процесу на основі інтегративного та особисто-орієнтованого підходу до навчання, які забезпечать розвиток у майбутніх дизайнерів широкого світогляду, емоційного інтелекту та можливості до суб'єктивно-об'єктивних висновків. Проте, ми зосереджуємо свою увагу на впровадженні критичного та екологічного підходів до інтерпретаційної підготовки фахівця, які матимуть позитивний вплив на формування: реальних знань на навичок професіонального будування логічних ментальних шляхів, щодо виявлення причинно-наслідкових зв'язків, а також усвідомлення першопричин (прихованих істин та системи цінностей) у формуванні концептуального положення, його формоутворенні у тому чи іншому творі мистецтва; розуміння першочергового (стандартного та індивідуального) алгоритму роботи з проектним проблемним завданням у будьякій сфері дизайну. Окресленні аспекти, на нашу думку, під час інтерпретаційної діяльності та у іiі кінцевому результаті, сприятимуть отриманню нового об'єктивного знання та його грамотного художньо-естетичного формотворення. Такі інтерпретаційні здобутки відповідатимуть реаліям суспільно-культурного розвитку та надаватимуть відповіді на заплутані питання сьогодення.

Стосовно розуміння сутності самого поняття «критичне мислення», то в цілому, дослідники А. Арсеньєв, Б. Ананьєва, Д. Дьюї, М. Лімпман, П. Щедровський, Р. Пауль, та ін., стверджують, що воно походить від «наукового 
мислення» та відрізняється від останнього, цілеспрямованим застосуванням раніше отриманого об'єктивного знання задля вирішення професійних й життєвих проблем у бутті. Засновник концепції критичного мислення М. Лімпман, розумів процес навчання не тільки як записування різноманітної інформації на довготривалу або короткочасну пам'ять, а й в першу чергу «культивування мудрості», яка трактується як вічне прагнення до осягнення нових істин та передачі широкого систематизованого спектра знань, позбавлених навіть найменшого елемента ілюзії [453, с. 4]. Людина як особистість, на думку Б. Ананьєва, не може уособлювати лише продукт історичного процесу, іiі мета та сенс існування - брати активну участь у формуванні щасливої власної долі та розвитку навколишнього світу. Психофізіологічна активність людини по своїй природі базується на постійному критичному аналізі та самостійному осмисленні всіх спектрів буття (минулого, теперішнього та майбутнього) [454, с. 9]. Проте, дослідник А. Арсеньєв, ключовою проблемою в організації навчальновиховного та інтерпретаційного процесу на базі критичного підходу бачить у недостатній вмотивованості та усвідомленні майбутніми дизайнерами власних професійних перспектив, від опанування навичками здорового критицизму [454, c. 24]. На це, науковці Р. Пауль та П. Щедровський, прогнозуючи тенденції розвитку особистості в умовах інформаційного суспільства, виділяють два головні аспекти мотивування студентів, щодо актуальності розвитку критичного мислення:

I. Модернізація техніки вже замінилася на вдосконалення людини та іiі особистісних якостей, тому що саме особистість є головним виробником інформації - головного капіталу постмодерністської світової наукової спільноти. Гнучкість розуму та швидкість в інтерпретації фактичного матеріалу - $\epsilon$ «цінними акціями», які будуть тільки збільшувати свою собівартість незалежно від спадів і підйомів на ринку праці й послуг;

II. Занепад духовності в технократичному суспільстві, боротьба за творчу наукову спадщину та природні ресурси, не сприяє просуванню основ демократичної та гуманістичної думки в соціумі. Натомість, критичне мислення 
допомагає оцінити обставини тієї чи іншої ситуації (локальної чи глобальної), що склалася 3 позиції чистого розуму та духу, а не холодного прагматичного розрахунку. Саме на такій гармонійній у своїй логічності основі, будуються вільні цивілізації, вирішуються конфлікти, щодо перетину інтересів і формується цілісна особистість, яка є істинним взірцем своєї країни [453, с. 5].

Однак Д. Дьюї, застерігає від чисто механічної технології розвитку критичного мислення, оперуючи лише прагматичними потребами. Він зауважує, що виховання вільного та дисциплінованого розуму формується шляхом внутрішнього споглядання, розгляду, контролю та зміни людиною ходу власних думок. Щодо системотворчих компонентів процесу рефлексії, то сюди він відносить наступні: по-перше, стан невизначеності від постійних сумнівів свідомості між вибором кращого варіанту розвитку подій, а також об'єктивної неможливості заглянути в майбутнє для підтвердження чи спростування одного 3 варіантів тут у сьогоденні; по-друге, процес пошуку, дослідження та абстрагування від несуттєвих варіантів, які лише перешкоджають руху вільної думки для досягнення мети інтерпретаційної діяльності [454, с. 28].

На нашу думку, за своєю природою процеси критичного мислення та художньо-естетичної інтерпретації схожі між собою, тому що обидва припускають: нестандартність руху думки в процесі пізнання, без готового зразка для репродуктивного наслідування; перехід від початкових поверхневих оціночних суджень до багатофакторного аналізу (соціально-економічного, культурно-історичного, психологічного, художньо-естетичного) та варіативності думки, щодо виявлення логічних взаємозв'язків конструктивних елементів у загальній системі; оперування правдивою науковою інформацією, задля формування суб'єктивно-об'єктивних висновків та продукування нового знання; беззаперечне прийняття позиції існування істини у предметі обговорення (виходу із ситуації) та логічної стратегії планування щодо іiі знаходження; подолання первинного страху «чистого аркуша», оскільки початок думки починається 3 відмови від попередніх догматичних рішень; усвідомлення процесу пізнання у вигляді ментальної моделі ланцюга циклічних 
герменевтичних кіл, кожне з яких характеризується максимальним розглядом загального та часткового (цілісністю знання) й елементом невизначеності (відкритістю знання), який продукує новий цикл розуміння.

Ми погоджуємося з вищезазначеними дослідниками, щодо актуалізації на сповільненому темпі пізнання та обробки фактичного матеріалу у процесі інтерпретаційної діяльності. Операція критичного мислення ретельно намагається виявити всі наявні взаємозв'язки між причинно-наслідковими аспектами будь-якої проблеми. Тому невиправдані та стрімкі імпульси тільки зашкодять зв'язку між інтерпретатором та твором, який було утворено при первинному осягненні останнього, але потребує аргументації міцності своєї концептуальної конструкції завдяки дедукції, індукції та загальної узгодженості матеріалу. Це необхідно, оскільки цінність критичного мислення полягає в його цілеспрямованості відшукати єдине правильне рішення в конкретних умовах. У цьому разі його об'єктивність апріорі $є$ дотичною до принципу наступності та перспективності наукового знання, адже включає відкритість шляхів, щодо подальшої побудови гіпотез. Окреслене стосується, як до конкретної проблеми в одній області (в залежності від мінливості подразників навколишнього середовища), так і до розширення міжпредметного спектра взаємозв'язків до вельми віддалених дисциплін з урахуванням розгляду навіть незначної ланки (на перший погляд) в конструкті нової для розуміння системи. До означеного можна віднести й здатність до сприйняття та повторення ірраціональних шляхів побудова думки, сюрреалістичних i парадоксальних концепцій - пізнання протилежностей в автономності один від одного та цілісності (полярності).

3 огляду на те, що метою критичного мислення - $\epsilon$ знаходження першопричини всього сущого, безсумнівно, даний процес є неможливим без грунтовного впровадження до дизайн-освіти екологічного підходу. Сучасне технократичне суспільство характеризується наявністю великої інформаційної бази для швидкого осягнення навколишньої дійсності (Інтернет, 3MI та TV), проте віртуальність ніколи не замінить безпосереднього діалогу з природним проявом сущого, а не його відформатованою імітацією у різноманітних образах. 
Адже, якщо природа, при цілеспрямованому та усвідомленому діалозі, формує й розвиває інтелектуальні, творчі, духовні та фізичні здібності людини, як частини вищої цінності, - то будь-який образ, є лише монологічною базою даних, щодо живого аналогу. Так, молодий дослідник, за твердженням С. Сухомлинського, ніколи не повинен забувати та нехтувати «колискою дитячої думки» природи, яку він уособлював із взаємовідношенням матері та дитини під час та після вагітності, як єдиний органічний симбіоз, а не граничні полярності сущого та людини [455, с. 3]. Такий глибинний зв'язок частини та цілого вищого порядку, не може бути розірвано, як під час інтерпретаційної діяльності, так й у житті в цілому. Проте, на нашу думку, є фактори, які грунтовно його послаблюють, а саме:

- зовнішній фактор - нагромадження та забруднення свідомості людини деструктивними догматичними ціннісними системами, 3 метою формування психічно-неврівноваженого індивіда-фанатика, який ніколи не зможе стати цілісною творчою особистістю, адже його світосприйняття грунтується на абстрактних положеннях, а не власному аналітичному та емпіричному досвіді 3 експериментальної перевірки реальності;

- внутрішній усвідомлений фактор - егоїстичні наміри людини щодо «діалогу довіри» із сущим у процесі інтерпретаційної діяльності, 3 метою маніакального володіння природно-біологічними та матеріально-технічними ресурсами у власних меркантильних інтересах, задля розташування своєї персони не просто у центрі буття, а над усім сущим - уподібнення себе до творчого Абсолюту;

- внутрішній неусвідомлений фактор - патологія інтелектуального розвитку людини у наслідок психофізіологічних відхилень від народження (синдромальна та ідіопатична інвалідність). У такому разі органічний зв'язок із сущім не носить замкнутого характеру апріорі, однак й науково-дослідною роботою інтерпретаційна діяльність також не відзначається (хоча, можливі й винятки, наприклад П. Пінеда, Б. Кравчук). 
Окреслені негативні прояви відмежування особистості від природного джерела натхнення та різноманіття художньо-естетичних образів, не аби як впливає на рівень чистоти та яскравості творчої уяви.

Нам імпонує думка С. Рубінштейна, стосовно того, що відтворення митцем ментальних конструкцій з розуміння естетичного компонента завдяки можливостям власної уяви - рівноцінно вже впровадженню дизайн-виробу до навколишнього середовища й отримання суб'єктивно-об’єктивного зворотного зв'язку від атмосфери інформаційного поля навколо нього [456, с. 372]. Адже, ще з античної давнини відомо просту формулу «людина $є$ мікрокосмосом, такою ж мірою, як Всесвіт уособлює собою макрокосм». Психічний процес уяви зазнає гармонійного розвитку тільки, якщо першим етапом його становлення $\epsilon$ художньо-естетична інтерпретація природного формотворення Всесвіту - «екотворчий аудит». Проте, дивитися на природу у процесі дозвілля - ще не означає iï бачити. Епізодичність у спілкуванні з природою викликає коливання енергоінформаційних потоків «динамічної рівноваги» уваги, що призводить до незбалансованості уяви, та як наслідок, до безглуздості художнього образу від поверховості й пустоти естетико-семантичного наповнення частин та цілого у ньому. Природа, за словами К. Ушинського є «могутнім агентом у вихованні людини», адже тільки через неї відкривається натуральний духовний компас до «наближення горизонтів» між сущім та його інтерпретатором [457, с. 3]. Художньо-проектна діяльність повинна починатися зі споглядання й розуміння естетичного ідеалу сущого, у варіативній доцільності усього його інтерпретаційного природного здобутку. Саме слово «ідеал» або «ейдос» - це першообраз вищої цінності Бога, а таким є тільки «любов», як вища абсолютна істина й благо. Прекрасне у природі не містить канонічної та стереотипної «штучної ідеальності» з їі статичною геометричністю пропорційності елементів цілого. Навпаки, воно завжди невимушене у своїй динамічний, асиметричній граціозності натурального нескінченного ритму краси, знаходячись поза часовими обмеженнями моди та стилю. Грунтуючись на концепції «філософії серця» Г. Сковороди, додамо, що сформована ментальна співзвучність 
емоціаналізму та критицизму митця й природи, сприяє справжньому інтелектуальному та психологічному розкріпаченню усієї спектральності творчого потенціалу людини.

Саме тому уява дизайнера не може розвиватися тільки на художньоестетичній інтерпретації архетипів будь-якого виду мистецтва, який вже зображує аспект еко-творчого аудиту іншої людини. Тільки індивідуальний критичний досвід такої діалектики надасть можливість проектувати концепти навіть найсміливіших фантасмагоричних проектів футуристичного дизайну, однак завжди з елементом реальності стратегічного впровадження у просторовочасовій динаміці буття. Так, на нашу думку, каталізаторами свідомого інтерпретаційного процесу задля продуктивної реалізації імпульсів уяви завдяки еко-творчому аудиту, повинні бути наступні умови:

- привчання студентів до гігієни власного внутрішнього інфополя завдяки формуванню чистоти наукових інтересів (соціальний аспект) i позитивних особистісних помислів (індивідуальний аспект), задля гармонійного «наближення горизонтів» у «діалозі довіри» 3 твором мистецтва. Забрудненість свідомості стереотипами, сумнівами, негативізмом, показною емоційністю та чуйністю - $є$ не опрацьованими страхами інтерпретатора, щодо власної особистості. Основу останніх становлять комплекси, а передостанніх застарілі образи. Все це непотрібні психологічні та інтелектуальні «якоря», які не дозволяють людині повною мірою розкріпачитися у своїй природності та відчути, навіть первинне цілісне емоційне враження від твору мистецтва;

- підвищення екологічної свідомості студентів шляхом розроблення дизайн-виробів на базисі еко-тренду художньо-проектної діяльності: виготовлення продуктів з натуральних матеріалів шляхом збереження аспекту ручної обробки поверхні; модифікація справжнього хутра та шкіри тварин на штучні замінники високої ергономічної якості, й водночас, економічними за ціновою політикою ринку; актуалізація уваги на захисті довкілля, завдяки своєчасному усуненню деструктивних проявів інтерпретаційного доробку (сміття, нечистот, виражених руйнацій формотворення та збоїв у функціонуванні 
- шум, випромінювання, вібрації) протягом усієї динаміки його життєвого циклу; стратегічної можливості делікатної утилізації виробу з мінімальними екологічними збитками та багаторазового використання (перероблювання) матеріалів - безвідходне виробництво;

- впровадження до програми підготовки теоретичних та практичних завдань 3 художньо-естетичної інтерпретації природних мотивів (цілісних пейзажів, елементів флори та фауни), а також комбінаторних варіантів композиції творів з урахуванням: візуалізації емоційних вражень мінорного, мажорного та нейтрального характеру від споглядання природи без яких-небудь штучних додаткових подразників (традиційні та інноваційні ігрові, розвивальні та музичні пристрої); визначення пропорційного співвідношення природного та імітаційного аспектів у творах різних видів мистецтв; створення власного асоціативного візуального ряду до певних світлових й температурних умов пір року; створення творчих копій відомих творів мистецтва, які перероблені в іншій стилістиці 3 урахуванням трансформації перспективної плановості, зміни фонового акценту (небо/земля, природа/місто, закритий простір/відкритий простір, архаїчний/модерністський та навпаки) та інтерпретації художнього образу (неживе перетворити у живе, та навпаки);

Отже, як бачимо, у процесі підготовки майбутніх дизайнерів до професійної інтерпретаційної діяльності, високий рівень критичного мислення, $\epsilon$ необхідним компонентом. Адже, для побудови концептуального рішення проекту, фахівець повинен оперувати достатньо великою кількістю різноманітного матеріалу, утримувати та подовжувати вектори дуки, щодо кожного знання, задля побудови індивідуального багатоаспектного логічного ланцюга. Саме така логіка початкового конструкта дизайн-проекту відповідає сутності поняття «креативність». Також, інтерпретаційний процес неможливий без прийняття своєї природи, знаходження в стані гармонії зі світом, позитивної установки, щодо світлого майбутнього, квінтесенцією яких є логічність динаміки розвитку всього природного цілого. 